\title{
DebT Characteristics KNOWLEDGE OF ENTREPRENEURS IN THE SME SECTOR OF THE CZECH REPUBLIC
}

\author{
Ludmila Kozubíková ${ }^{1}$, Robin Klička ${ }^{2}$; Darek Maňák ${ }^{3}$ \\ Tomas Bata University in Zlín, \\ Faculty of Management and Economics, Department of Enterprise Economics, \\ Mostní 5139, 76001 Zlín, Czech Republic \\ e-mail: ${ }^{1}$ kozubikova@fame.utb.cz; ${ }^{2}$ robinklicka@gmail.com; ${ }^{3}$ manakdarek@gmail.com
}

\begin{abstract}
Due to lack of internal and own sources in small and medium-sized enterprises (SMEs), the debt financing is an inevitable part of a total amount of capital used in business. The aim of this paper is to find out what knowledge of debt financing (e.g., in the sense of its costs and risk) the SMEs entrepreneurs have. We also tried to reveal the differences regarding such knowledge in relation to age and education of the entrepreneurs and the length of doing their business. The data was collected through the questionnaire survey undertaken on the sample of 352 SMEs entrepreneurs in the Czech Republic. Our results revealed that $83 \%$ of entrepreneurs understand the most important aspects of credit risk and $73 \%$ of them think that an entrepreneur needs to use a certain amount of loans. There were found statistically significant differences in this statement between male and female entrepreneurs.
\end{abstract}

\section{Keywords}

Small and medium-sized enterprises; Debt; Credit risk; Age; Education; Length of doing business; Czech Republic.

\section{Introduction}

Small and medium-sized enterprises (SMEs) have the utmost importance in modern economies due to their quick adaptation to changes in business conditions, and due to their significant contribution to the economic growth. However, a firm's survival is the major issue for small businesses due to entrepreneurs' lack of strategic behaviour, and due to suppressive behaviour from the large corporate firms. [29]

In total, the SME sector is represented by more than one million enterprises and it employs almost two thirds of all employees in the Czech Republic [17]. SMEs are not only an integral part of the Czech Republic economy, but they are also extremely important for the whole European Union.

Despite many advantages, the entrepreneurship of SMEs has also many limitations and constraints, e.g. much smaller economic power, very often a difficult access to finance and consequently limited capacity-building options. According to Synek [34], SMEs are considered to be risky clients. Because of this fact, obtaining loans is too difficult for these enterprises. Moreover, this aspect is also a reason for having worse credit conditions of banks for SMEs without respecting a good business plan. Delic, Peterka and Kurtovic [6] state that high collaterals are one of the biggest obstacles to financing through debt for small and medium-sized enterprises, which, on the other hand, cannot be decreased without institutional development as well as development of the financial market. 
It is generally known that loans can decrease the total capital costs due to interest tax shield even though they are more risky than equity. It is important for the SMEs' entrepreneurs to know about the advantages and disadvantages of using loans. The SMEs' entrepreneurs can get such knowledge through their educational process, in various courses, or just from experience. It is also possible that they do not have any knowledge of this kind. Due to the fact that not much information with regard to this knowledge in the SME segment has been published, we would like to extend it through this paper.

This article has the following structure: in the theoretical part, the essential attributes of using loans in a capital structure of SMEs, the knowledge of credit risk, the advantages and disadvantages of this form of capital, and the role of gender and education of entrepreneurs and the length of doing business are introduced. In the next section, there are presented objectives, methodology and resources of information used in the research. Finally, the most important recommendations for the theoretical area as well as economic practice and limits of this study and possibilities of future research are stated.

\section{$1 \quad$ Theoretical background}

An entrepreneur must be a person who is able to take a risk and understand the possibility of failure of his/her decision. In general, women are more risk averse than men. For example, Forlani [8] indicates that women believe less in their abilities to make financially risky business development-type decisions than men do, and that these beliefs are unsubstantiated.

The analysis of Kepler and Shane [14] shows that male entrepreneurs were significantly less likely to prefer low-risk/low-return businesses than female entrepreneurs.

The issue of capital costs and risk connected with loans finally leads to a search for an optimal capital structure. Since Modigliani and Miller [24] first proposed the MM theory that a capital structure is irrelevant to determining corporate value in a non-friction (perfect) market in 1958, the issue of capital structure has generated great interest among financial economists represented by the trade-off theory, the agency cost theory, the pecking order theory and the equity timing market theory. It is argued that agency costs arise from conflicts between two parties, namely the principle and the agent (e.g., owners and managers) within firms. Leverage has been deemed as an instrument of the first perception to reduce agency costs (the use of debt can effectively displace equity capital) and remaining borrowing at higher levels might increase the probability of bankruptcy and job loss, and resolve the free cash flow problem [19]. According to Delic et al. [6], agency costs are particularly devastating for external financing of the SME sector, primarily because of the quality of information that the owner, i.e., a manager of a SME provides to the financial institution.

Financial knowledge is one of the most important determinants of a capital structure that enables growth and development of the SME sector as well as a greater competitiveness of enterprises, regardless of size, activity, industry and the form of ownership of these enterprises. An efficient risk-taking is primarily reflected in the availability of a large number of sources of funding, which enables enterprises to have freedom when forming their capital structure. Enterprises that do not have a large number of sources of funding at their disposal have to resort to debt financing when forming their capital structure, which ultimately means excessive financial vulnerability. [6]

SMEs cannot avoid the general existence of financial risk that has a certain influence on their production and management. In order to survive in the challenging market competition and put forward effective prevention and control measures, and thus lower the possibility of occurrence of risks to ensure their development, SMEs need to have a full understanding of the characteristics and the causes of financial risk in relation to their enterprises. [15] 
In general, an entrepreneurial risk can be understood as the possibility that real results will not meet the expected results [9]. Part of these risks is also a financial risk that includes a credit risk. The authors consider the credit risk as a risk connected with insolvency or payment refusal of customers. In fact, it is possible that a contracting party does not meet its obligations of repaying the debt, paying an invoice, etc. Shuying and Mei [33] argue that financial risk is one of major reasons for SMEs default. A poor capital structure of SMEs is another major reason for financial risk. The authors propose that effective management of a capital structure can reduce the debt burden and the financial risk of SMEs.

Joseph [13] defines the credit risk as probability of loss caused by granting credit because of not meeting obligations of a contracting counterparty. All above-stated for the reason of unwillingness, incapability or any other reason that does not enable a counterparty to meet its obligations. If the probability of loss is high, then the credit risk is also high and vice versa.

Režňáková [31] distinguishes different types of credit risk, e.g. the risk of insolvency (it is caused by a worsening debtor's financial situation), the risk of payment default (it is caused by unwillingness to pay the liabilities in time), the risk of postponing payments, the risk of extending a due period of the invoice and territorial risk.

For comparison, Jílek [12] divides credit risk into four categories: direct credit risk (risk of loss caused by a partner's failure regarding traditional balance sheet items), the risk of credit equivalents (risk of loss caused by a partner's failure regarding off balance items), the risk of paying/not paying loans (risk of loss caused by failure of transactions in the process of paying loans), the risk of credit involvement (risk of loss when being involved with individual partners).

However, firm risk may be strategic as well as structural. Irrespective of age and size considerations, firms adopting specific strategies may face an increased risk and uncertainty. Riskier strategies increase perceived environmental uncertainty and, from the perspective of potential funders, information opacity. [32]

Various types of research clearly show that the access to finance is one of the main challenges for the growth and development of entrepreneurs, especially in the SME sector. $[1 ; 2 ; 16]$

The demand and supply of finance to the SME sector involves more complex issues than applied to large firms. SME owners' patchy knowledge of funding opportunities may reflect not sufficient skills and knowledge of their business advisors, especially accountants. The search for finance is impeded by business characteristics such as size, age, profitability and growth objectives. [7]

Other researches show that the access to finance and credit costs is not a small constraint on financing SMEs [1;2]. Binks and Ennew [4] consider in their study lack of access to finance together with job skills, management and government regulations to be the main constraints on the SMEs growth.

The results of Mc Namara, Murro and O'Donohoe [21] suggest that countries' lending infrastructure influences the SMEs' capital structure. It is evident that the SME debt is higher in countries with more efficient bankruptcy environments in terms of debt recovery as well as in countries with less stringent regulatory environments by having lower capital regulatory requirements for banks. In case the control variables are missing, many of the lending infrastructure components appear significant. These include information, legal and regulatory environments together with bankruptcy and regulatory regimes.

Lending to small firms (and lending smaller amounts) carries disproportionately higher costs of due diligence with these costs inflated, facing limited credit histories or audited financial 
statements [35]. For these reasons, mainly, smaller firms have historically been identified as especially susceptible to credit rationing. [32]

The empirical research shows that asymmetric information and agency costs in small business lending can be alleviated by imposing a shorter loan maturity because it will reduce the riskshifting behaviour of the borrower $[3 ; 26]$

Rostamkalaei and Freel [32] state that discouraged borrowers do not apply for credit because they are afraid of rejection - despite their declared neediness and despite being observationally indistinguishable from those who have applied for and have received money. There is also evidence that some entrepreneurs face initial rejection or are presented with unsuitable terms of contract at the first attempt and must re-apply, renegotiate or switch banks for a better deal.

The results of Ključnikov and Belás [15] indicate that management and owners of smaller companies have inferior or insufficient financial knowledge and lack of management skills, which leads to a lower perception of the importance of credit risk during the crisis. In this context, it is interesting to note that the level of knowledge of credit conditions is relatively low. Only a small part of the SME entrepreneurs is well informed about conditions under which commercial banks provide loans.

Regarding gender, Treichel and Scott [35] found out that gender does appear to be related to some aspects of access to bank financing. Specifically, gender is significantly related to the application for bank loans as well as size of the loans, and these effects persist over time. They also revealed that women-owned businesses are significantly less likely to apply for a bank loan. Their results suggest that there is no likely difference in approval of the loans to women- and men-owned businesses after controlling firm's characteristics.

The study of Garwe and Fatoki [10] confirmed that gender does not have any significant impact on the SME finance, however, females were more discouraged from bank finance than males due to the fact that females were afraid of rejection because of lack of education and lack of personal assets or collateral.

Higher education of the entrepreneurs had an impact on getting rid of the problem with financial restrictions, and it can be generally said that higher education of an entrepreneur helps to remove the problem with the access to finance in comparison with the impact of gender and ethnicity. [11]

According to North, Baldock and Ekanem [25], the influence of such factors as size and age of the company seems to influence its access to the credit financing. New and early-stage SMEs are facing more intensive problems with the bank financing than their more established counterparts. In comparison with the results of Klujčnikov and Belás [15], older companies perceive the growth of credit risk more intensively than the younger ones.

According to Yazdanfar and Öhman [37], older firms tend to rely less on debt capital than younger ones do. This may be for the reason that older firms are aware of opportunities to use internal financing sources more than their younger counterparts are.

\section{Research Objective, Methodology, Data}

\subsection{Research Objective}

The aim of this paper is to find out what knowledge of debt financing (e.g. in the sense of its costs and risk) the SMEs' entrepreneurs in the Czech Republic have. We also tried to reveal the differences in such knowledge in relation to gender and education of the entrepreneurs and the length of doing business. 
In accordance with the objectives, we have chosen five statements from the questionnaire that was used, and through chi-square and p-value, we tried to reveal statistically significant differences in the overall structure of responses to each statement in each defined group (between entrepreneurs men and women, university-educated and otherwise educated entrepreneurs, entrepreneurs doing their business for less and more than 10 years). Consequently, we tried to reveal statistically significant differences inside of each studied group in affirmative and discrepant answers and in neutral answers. We chose the following statements from the questionnaire:

\section{Statement I: "I understand the most important aspects of credit risk."}

Statement II: "Loans (a bank loan) are cheaper than equity of an entrepreneur, therefore I make use of a bank credit."

Statement III: "Loans (a bank loan) are less risky than equity, therefore I use the service of borrowing money from a bank."

Statement IV: "When doing business, a certain amount of loans is necessary. However, I think an entrepreneur should have more equity than the loans."

Statement V: “Loans should be first used for financing current assets of a company."

We aimed at entrepreneurs of SMEs defined in Annex 1 to Commission Regulation (EU) No. 651/2014. The category of microenterprises, small and medium-sized enterprises consists of the companies which employ less than 250 employees and their annual turnover does not exceed 50 million EUR or whose annual balance sheet in total does not exceed 43 million EUR. Within this category a small enterprise is defined as an enterprise employing less than 50 people and whose annual turnover or annual balance sheet in total does not exceed 10 million EUR. Microenterprises are defined as the enterprises which employ less than 10 people and whose annual turnover or annual balance sheet in total does not exceed 2 million EUR. [23]

\subsection{Research Methodology and Data}

The research into business environment was carried out in the Czech Republic throughout the period of November 2016 to February 2017. The companies surveyed were chosen from the database Albertina and 2,100 randomly selected firms were addressed by e-mail of phone to fill in the questionnaire placed at website

https://docs.google.com/forms/d/e/1FAIpQLSc8VFW1EzSfjCqVCPTtt4ZozjBpMlXbAnkyn8 KGvYQCflKkOQ/viewform.

We asked purposefully the owner or one of the owners of selected SMEs or chief manager to fill in the questionnaire. Finally, the data was provided by 352 entrepreneurs of SMEs in 14 regions of the Czech Republic. The questionnaire consisted of 42 questions. In this context, in the first six questions, the structure of respondents in relation to their education, gender, residency and size of a firm, the length and area of doing business were analyzed. The rest of the questions were questions on a 1-5 scale (1 - totally agree, 2 - agree, 3 - no opinion, 4 disagree, 5 - completely disagree) focused on knowledge and conditions of debt financing.

The structure of the respondents with the use of descriptive statistics according to geographical locations of companies in the Czech regions was as follows: Zlín (20\%), Moravia-Silesia (13\%), Olomouc (8\%), South Moravia (5\%), Liberec (24\%), Prague (8\%), Pardubice (2\%), Plzeň (1\%), Central Bohemia (6\%), Hradec Králové $(7 \%)$, Vysočina $(2 \%)$, South Bohemia (1\%), Ústí nad Labem (2\%), and Karlovy Vary (2\%). 
Majority of respondents were men $(75 \%)$ and the rest of them $(25 \%)$ were female entrepreneurs. Most of the entrepreneurs in the sample, more precisely 39\%, had secondary education, $49 \%$ of them had university education, and $12 \%$ had secondary education without graduation examination.

The structure of the sample with regard to the business area was as follows: trade companies (26\%), manufacturing companies (18\%), construction companies (13\%), transport companies (3\%), and agricultural firms (4\%). The largest portion of companies operated in other sectors $(37 \%)$.

Regarding the length of doing business, out of 352 companies, 64\% of them were doing business for more than 10 years, $17 \%$ of them between 1 to 5 years, and $18 \%$ of them between 5 to 10 years. It can be stated that the owners of the companies were rather experienced entrepreneurs.

Out of 352 companies surveyed, $66 \%$ of them were microenterprises, $19 \%$ were small enterprises and $15 \%$ were medium-sized enterprises.

Different authors search the issue of the importance of gender in entrepreneurship in general and also specifically in relation to risk taking as an element of entrepreneurial orientation. For example Langowitz a Minniti [18] found out that women are more risk averse than men and men's willingness to risk does not prevent them from starting a business.

The issue of entrepreneurs' education is discussed by many researchers. For example Rauch and Rijsdijk [30] and Millán et al. [22] showed that higher education can positively influence business performance and according to Wang [36] it can improve management of financial risks.

According to Marques et al. [20] cognitive factors such as exposure to high risk, recognition of opportunities and perception of probability of success are related to experience. Pervan and Kuvek [27] and Canton et al. [5] state that the length of doing business besides the size of a company can play an important role in obtaining external financial resources.

For the purpose of this paper with respect to the above stated opinions of different authors we have selected the following sociodemographic factors: gender and education of entrepreneurs and the length of doing business as important factors influencing the attitude to using debt in business and also knowledge of debt financing and relating financial risk. The rest of the factors (business area, regions of the Czech Republic) were not taken into account in this article.

Following the findings and taking into account gender, education and the length of doing business as selected factors influencing knowledge of debt financing and attitude to financial risk, we have stated the following five basic hypotheses. Moreover, in relation to the selected factors of gender, education and the length of doing business, we have set other three hypotheses to verify and achieve a secondary aim of the paper:

$H_{1}$ : I understand the most important aspects of credit risk. At least $65 \%$ of respondents agree with this statement.

$\mathrm{H}_{2}$ : Loans (a bank loan) are cheaper than equity of an entrepreneur, therefore I make use of a bank credit. At least $50 \%$ of respondents agree with this statement.

$H_{3}$ : Loans (a bank loan) are less risky than equity, therefore I use the service of borrowing money from a bank. A maximum of $40 \%$ of respondents agree with this statement. 
$H_{4}$ : When doing business, a certain amount of loans is necessary. However, I think an entrepreneur should have more equity than the loans. At least $70 \%$ of respondents agree with this statement.

$H_{5}$ : Loans should be first used for financing current assets of a company. A maximum of $45 \%$ of respondents agree with this statement.

$H_{6}$ : There are no statistically significant differences with regard to gender of respondents in the responses to statements $\mathrm{I}-\mathrm{V}$.

$\mathrm{H}_{7}$ : There are statistically significant differences with regard to education of respondents in the responses to statements I-V. University-educated respondents understand terms of using debt financing statistically better than respondents with other types of education.

$H_{8}$ : There are statistically significant differences with regard to the length of doing business in the responses to statements I-V. More experienced entrepreneurs (being in business for more than 10 years) understand terms of using debt financing statistically better than younger enterprises.

To assess statistical statements in the area of financial risk, we used the following statistical tools of descriptive statistics: tables, descriptive characteristics - average, scattering, and score. The score is calculated by adding all the evaluations. Next, we applied statistical methods such as absolute quantity and simple classification of a statistical marker, classification according to two statistical markers.

The associations in contingency tables were analyzed by Pearson statistics in order to count the data. $P$-value was compared to a standard confidence level of $5 \%$. P-value that is lower than the confidence level leads to rejection of the null hypothesis. The null means that there is no association between variables. We used a double-choice $t$-test (non-pair). We tested whether the difference of mean values between the sets is zero (zero hypothesis) in contrast to a non-zero difference between mean values (alternative hypothesis). All the tests were done on the level of significance 0.05 . The critical values of acceptance or refusal of the zero hypothesis with the use of number of degrees of leeway are provided in the subject data evaluation in the tables $(t$-Statistics and $p$-value $(P(T<=t)))$. The prerequisites for doing this test such as regular distribution of the data in the sets, independence of the sets, even variance between the sets were a subject to scrutiny before the actual $t$-test. For verification of the normality assumption, we used a graphic analysis of the data (a comparison of data's histogram in a set with a curve of normal distribution), but we also tested with the use of Chisquare test of good agreement (goodness-of-fit). For verification of statistically irrelevant differences in scattering, we used the F-test. All conditions for doing the double-choice $t$-test (non-pair) were met. The calculations were done by using sophisticated statistics software, SPSS Statistics.

\section{$3 \quad$ Results and Discussion}

In Table 1 we present results of different attitudes of men and women to the statements examined $(\mathrm{I}-\mathrm{V})$. 
Tab. 1: Differences in knowledge of debt financing in relation to gender of the entrepreneurs

Notes:

\begin{tabular}{|c|c|c|c|c|c|c|c|c|c|c|c|}
\hline \multirow[t]{2}{*}{ GENDER } & \multicolumn{5}{|c|}{$\begin{array}{l}\text { Men } \\
(265)\end{array}$} & \multicolumn{5}{|c|}{$\begin{array}{c}\text { Women } \\
(87)\end{array}$} & \multirow{2}{*}{$\begin{array}{c}\text { Chi-square } \\
P \text {-value }\end{array}$} \\
\hline & -2 & -1 & 0 & 1 & 2 & -2 & -1 & 0 & 1 & 2 & \\
\hline \multirow{2}{*}{$\begin{array}{l}\text { Statement I } \\
\text { (in \%) }\end{array}$} & 0 & 10 & 33 & 171 & 51 & 2 & 7 & 9 & 54 & 15 & 5.7691 \\
\hline & 0 & 4 & 12 & 65 & 19 & 2 & 8 & 10 & 62 & 17 & 0.2171 \\
\hline \multirow{2}{*}{$\begin{array}{l}\text { Statement II } \\
\text { (in \%) }\end{array}$} & 28 & 98 & 55 & 70 & 14 & 6 & 32 & 25 & 21 & 3 & 3.3373 \\
\hline & 11 & 37 & 21 & 26 & 5 & 7 & 37 & 29 & 24 & 3 & 0.5030 \\
\hline \multirow{2}{*}{$\begin{array}{l}\text { Statement III } \\
\text { (in \%) }\end{array}$} & 40 & 122 & 56 & 43 & 4 & 5 & 42 & 25 & 13 & 2 & 6.4996 \\
\hline & 15 & 46 & 21 & 16 & 2 & 6 & 48 & 29 & 15 & 2 & 0.1648 \\
\hline \multirow{2}{*}{$\begin{array}{l}\text { Statement IV } \\
\text { (in \%) }\end{array}$} & 3 & 46 & 33 & 128 & 55 & 1 & 5 & 10 & 57 & 14 & 10.5641 \\
\hline & 1 & 17 & 12 & 48 & 21 & 1 & 6 & 11 & 66 & 16 & 0.0319 \\
\hline \multirow{2}{*}{$\begin{array}{l}\text { Statement V } \\
\text { (in \%) }\end{array}$} & 15 & 81 & 81 & 82 & 6 & 6 & 25 & 32 & 23 & 1 & 1.8841 \\
\hline & 6 & 31 & 31 & 31 & 2 & 7 & 29 & 37 & 26 & 1 & 0.7571 \\
\hline
\end{tabular}

-2 - absolutely disagree, -1 - disagree, 0 - no opinion, 1 - agree, 2 - absolutely agree.

Numbers in \% were rounded to whole numbers (e.g., 1.56 rounded to 2) and calculated, e.g., as the amount of men absolutely agreeing with the statement I (51) compared to the total amount of men (265), which is $19 \%$.

Source: Own calculation

Regarding the aspect of gender, the final values of test criteria (chi-square, p-value) have confirmed that there are statistically significant differences in the overall structure of answers of male entrepreneurs in comparison with female entrepreneurs only in statement IV $(10.5641 / 0.0319)$.

Female entrepreneurs agreed with the opinion on having more equity than debt statistically more often ( 71 out of 87 , which is $82 \%$ ) than their male counterparts (183 out of 265 , which is $69 \%$ ). This fact can be connected with a different risk attitude in relation to gender because women are generally more risk-averse than men $[8 ; 14 ; 28]$.

In Table 2, we present a different attitude of university-educated and other educated respondents (secondary-educated and secondary-educated without graduation).

Regarding education, the final values of test criteria (chi-square, $p$-value) have confirmed that there are statistically significant differences in the overall structure of answers of universityeducated entrepreneurs in comparison with other educated entrepreneurs only in statement II (16.7662 / 0.0215).

University-educated respondents agreed statistically more often (69 out of 171, which is $40 \%$ ) with the statement that loans are cheaper than equity in comparison with others (39 out of 181 , which is $22 \%$ ). If the university-educated respondents graduated from economic faculties, it is logical that they should have a certain level of knowledge of the capital costs. 
Tab. 2: Differences in knowledge of debt financing in relation to education of the entrepreneurs

\begin{tabular}{|c|c|c|c|c|c|c|c|c|c|c|c|}
\hline \multirow[t]{2}{*}{ EDUCATION } & \multicolumn{5}{|c|}{$\begin{array}{c}\mathrm{UE} \\
(\mathbf{1 7 1})\end{array}$} & \multicolumn{5}{|c|}{$\begin{array}{c}\text { OE } \\
(181)\end{array}$} & \multirow{2}{*}{$\begin{array}{l}\text { Chi-square } \\
P \text {-value }\end{array}$} \\
\hline & -2 & -1 & 0 & 1 & 2 & -2 & -1 & $\mathbf{0}$ & 1 & 2 & \\
\hline \multirow{2}{*}{$\begin{array}{l}\text { Statement I } \\
\text { (in \%) }\end{array}$} & 1 & 6 & 16 & 111 & 37 & 1 & 11 & 26 & 114 & 29 & 4.5808 \\
\hline & 1 & 4 & 9 & 65 & 22 & 1 & 6 & 14 & 63 & 16 & 0.3307 \\
\hline \multirow{2}{*}{$\begin{array}{l}\text { Statement II } \\
\text { (in \%) }\end{array}$} & 12 & 52 & 38 & 57 & 12 & 22 & 78 & 42 & 34 & 5 & 16.7662 \\
\hline & 7 & 30 & 22 & 33 & 7 & 12 & 43 & 23 & 19 & 3 & 0.0215 \\
\hline \multirow{2}{*}{$\begin{array}{l}\text { Statement III } \\
\text { (in \%) }\end{array}$} & 18 & 78 & 41 & 30 & 4 & 27 & 86 & 40 & 26 & 2 & 2.8732 \\
\hline & 11 & 46 & 24 & 18 & 2 & 15 & 48 & 22 & 14 & 1 & 0.5793 \\
\hline \multirow{2}{*}{$\begin{array}{l}\text { Statement IV } \\
\text { (in \%) }\end{array}$} & 2 & 31 & 27 & 81 & 30 & 2 & 20 & 16 & 104 & 39 & 8.9430 \\
\hline & 1 & 18 & 16 & 47 & 18 & 1 & 11 & 9 & 57 & 22 & 0.0625 \\
\hline \multirow{2}{*}{$\begin{array}{l}\text { Statement V } \\
\text { (in \%) }\end{array}$} & 8 & 43 & 65 & 52 & 3 & 13 & 63 & 48 & 53 & 4 & 7.3958 \\
\hline & 5 & 25 & 38 & 30 & 2 & 7 & 35 & 27 & 29 & 2 & 0.1164 \\
\hline
\end{tabular}

Notes:

UE - university education, OE - other education (secondary education and secondary education without graduation)

-2 - absolutely disagree, -1 - disagree, 0 - no opinion, 1 - agree, 2 - absolutely agree.

Numbers in \% were rounded to whole numbers (e.g., 1.56 rounded to 2) and calculated, e.g., as the amount of UE absolutely agreeing with the statement I (37) compared to the total amount of UE (171), which is $22 \%$.

Source: Own calculation

Results of different attitudes to the statements examined ( $\mathrm{I}-\mathrm{V})$ in relation to the length of doing business are presented in Table 3 .

Tab. 3: Differences in knowledge of debt financing in relation to the length of doing business

\begin{tabular}{|c|c|c|c|c|c|c|c|c|c|c|c|}
\hline \multirow{2}{*}{$\begin{array}{l}\text { LENGTH } \\
\text { OF DOING } \\
\text { BUSINESS }\end{array}$} & \multicolumn{5}{|c|}{$\begin{array}{c}-10 \\
(125)\end{array}$} & \multicolumn{5}{|c|}{$\begin{array}{l}+10 \\
(227)\end{array}$} & \multirow{2}{*}{$\begin{array}{c}\text { Chi-square } \\
P \text {-value }\end{array}$} \\
\hline & -2 & -1 & 0 & 1 & 2 & -2 & -1 & 0 & 1 & 2 & \\
\hline \multirow{2}{*}{$\begin{array}{l}\text { Statement I } \\
\text { (in \%) }\end{array}$} & 0 & 5 & 17 & 76 & 27 & 2 & 12 & 25 & 149 & 39 & 1.8600 \\
\hline & 0 & 4 & 14 & 61 & 22 & 1 & 5 & 11 & 66 & 17 & 0.7615 \\
\hline \multirow{2}{*}{$\begin{array}{l}\text { Statement II } \\
\text { (in \%) }\end{array}$} & 11 & 51 & 28 & 29 & 6 & 23 & 79 & 52 & 62 & 11 & 1.4703 \\
\hline & 9 & 41 & 22 & 23 & 5 & 10 & 35 & 23 & 27 & 5 & 0.8319 \\
\hline \multirow{2}{*}{$\begin{array}{l}\text { Statement III } \\
\text { (in \%) }\end{array}$} & 17 & 65 & 25 & 16 & 2 & 28 & 99 & 56 & 40 & 4 & 3.2722 \\
\hline & 14 & 52 & 20 & 13 & 2 & 12 & 44 & 25 & 18 & 18 & 0.5134 \\
\hline \multirow{2}{*}{$\begin{array}{l}\text { Statement IV } \\
\text { (in \%) }\end{array}$} & 2 & 16 & 23 & 62 & 22 & 2 & 35 & 20 & 123 & 47 & 7.5351 \\
\hline & 2 & 13 & 18 & 50 & 18 & 1 & 15 & 9 & 54 & 21 & 0.1102 \\
\hline \multirow{2}{*}{$\begin{array}{l}\text { Statement V } \\
\text { (in \%) }\end{array}$} & 6 & 38 & 38 & 40 & 3 & 15 & 68 & 75 & 65 & 4 & 1.0929 \\
\hline & 5 & 30 & 30 & 32 & 2 & 7 & 30 & 33 & 29 & 2 & 0.8954 \\
\hline
\end{tabular}

Notes:

-10 - enterprises doing business for less than 10 years, +10 - enterprises doing business for more than 10 years,

-2 - absolutely disagree, -1 - disagree, 0 - no opinion, 1 - agree, 2 - absolutely agree.

Numbers in \% were rounded to whole numbers (e.g., 1.56 rounded to 2 ) and calculated, e.g., as the amount of 10 absolutely agreeing with the statement I (27) compared to the total amount of -10 (125), which is $22 \%$.

Source: Own calculation

Regarding the length of doing business, the final values of test criteria (chi-square, $p$-value) have not confirmed any statistically significant differences in the overall structure of the answers of enterprises being in business for less than 10 years in comparison to the enterprises being in business for more than 10 years. 
In our research, 261 respondents $(82.67 \%)$ understand the most important aspects of credit risk (statement I). Within the designated groups, university-educated entrepreneurs $(87 \%)$ most frequently reported this answer. $H_{1}$ was confirmed. A relatively high percentage of entrepreneurs familiar with properties of capital is a positive result. This corresponds with the results of research carried out by Delic et al. [6] in Croatia which indicate that $95.4 \%$ of respondents (owners and/or managers of SMEs) highlighted the importance of knowing the strengths and weaknesses of individual sources of financing (financial literacy) as an important factor when making decisions about a capital structure.

108 respondents $(30.68 \%)$ think that loans are cheaper than equity; therefore, they make use of bank loans. The most frequently reported answer was again by university-educated entrepreneurs (40\%). $\mathrm{H}_{2}$ was not confirmed because less than $50 \%$ of respondents agreed with statement II.

The answers to the statement III were affirmative in 62 responses (17.61\%). 62 respondents consider debt to be less risky than equity and it is the reason why they use credit in their business. $H_{3}$ was confirmed because only $17.61 \%$ of respondents agreed with the statement III, which is less than a considered value of $40 \%$ set as the maximum value in hypothesis $\mathrm{H}_{3}$.

In our research, 254 respondents $(72.16 \%)$ think that an entrepreneur needs to use a certain amount of loans but they think that an entrepreneur should have a larger amount of equity than loans (statement IV). $H_{4}$ was confirmed because more than $70 \%$ of respondents agreed with statement $\mathrm{V}$.

112 respondents out of 352 respondents $(31.82 \%)$ agree with the opinion that debt should be preferably used to finance current assets of the enterprise (statement V). $H_{5}$ was confirmed because the final value of $31.82 \%$ is below the considered value of $45 \%$.

Results on $Z$-score from $P$-value to reveal the statistically significant differences in affirmative, neutral, and dissenting responses in each statement are presented in Table 4. For this purpose, we merged the answers "absolutely agree" (2) and "agree" (1) in a single value, and in the same way we merged "absolutely disagree" $(-2)$ and "disagree" $(-1)$.

Tab. 4: Differences inside the groups in relation to gender, education and the length of doing business

\begin{tabular}{|l|c|c|c|c|c|c|c|c|c|}
\hline \multirow{2}{*}{$\begin{array}{l}\text { FROMUE } \\
\text { Z-SCORE }\end{array}$} & \multicolumn{3}{|c|}{ Men / Women } & \multicolumn{3}{c|}{ UE / OE } & \multicolumn{3}{c|}{$\mathbf{- 1 0} /+\mathbf{1 0}$} \\
\cline { 2 - 10 } & $\mathbf{- 2 , - 1}$ & $\mathbf{0}$ & $\mathbf{1 , 2}$ & $\mathbf{- 2 , - 1}$ & $\mathbf{0}$ & $\mathbf{1 , 2}$ & $\mathbf{- 2 , - 1}$ & $\mathbf{0}$ & $\mathbf{1 , 2}$ \\
\hline Statement I & 0.0188 & 0.5961 & 0.3421 & 0.2937 & 0.1471 & 0.0615 & 0.3898 & 0.4715 & 0.9203 \\
\hline Statement II & 0.5287 & 0.1236 & 0.4715 & 0.0008 & 0.8259 & 0.0001 & 0.4009 & 0.9124 & 0.4179 \\
\hline Statement III & 0.2420 & 0.1443 & 0.9124 & 0.2301 & 0.6745 & 0.2757 & 0.0784 & 0.3173 & 0.2420 \\
\hline Statement IV & 0.0099 & 0.8103 & 0.0232 & 0.0658 & 0.0466 & 0.0032 & 0.6384 & 0.0085 & 0.1236 \\
\hline Statement V & 0.9203 & 0.2801 & 0.3271 & 0.0173 & 0.0209 & 0.8887 & 0.8026 & 0.6101 & 0.4413 \\
\hline
\end{tabular}

Notes:

-10 - enterprises doing business for less than 10 years, +10 - enterprises doing business for more than 10 years, $\mathrm{UE}$ - university education, $\mathrm{OE}$ - other education,

-2 - absolutely disagree, -1 - disagree, 0 - no opinion, 1 - agree, 2 - absolutely agree.

Source: own calculation

The final values of test criteria ( $P$-value from $Z$-score) revealed statistically significant differences in dissenting answers in statement I between male and female entrepreneurs (0.0188). Female entrepreneurs statistically more often stated (9 women out of 87, which is $10.34 \%$ ) that they understood the most important aspects of credit risk in comparison with male entrepreneurs (10 men out of 265 , which is $3.77 \%$ ). Regarding gender, statistically 
significant differences were also found out in both affirmative and dissenting answers to statement IV. Female entrepreneurs are statistically more aware (71 out of 87 , which is $87.61 \%$ ) of the fact that an entrepreneur needs a certain amount of loans but he/she should have more equity than loans in comparison with male (183 out of 265 , which is $69.06 \%$ ). These results correspond with statistically less significant dissenting responses of female entrepreneurs to this question (6 out of 87 , which is $6.90 \%$ ) in comparison with male entrepreneurs (49 out of 265 , which is $18.49 \%$ ). $H_{6}$ was partially confirmed (in statements II, III, V).

In statement II, there were revealed statistically significant differences both in affirmative and dissenting answers between university-educated ones and others ( $P$-value from $Z$-score: 0.0008 in dissenting ones; 0.0001 in affirmative answers). 100 respondents out of 181 respondents with secondary education or secondary education without graduation $(55.25 \%)$ do not think that they understand the most important aspects of credit risk. These results are supported by the results in affirmative answers because university-educated respondents think that they understand the most important aspects of credit risk statistically better (69 out of 171 , which is $40.35 \%$ ) than other educated entrepreneurs (39 out of 181, which is 21.55). Regarding education, we have also found out statistically significant differences in statements IV and V. In statement IV, other educated respondents more often agreed (143 out of 181, which is $79 \%$ ) with the need of having loans in business in comparison with universityeducated ones (111 out of 171 , which is $64.91 \%$ ). In statement V, other educated entrepreneurs more often did not agree ( 76 out of 181 , which is $41.99 \%$ ) with the opinion that loans should be used especially for financing current assets in comparison with universityeducated ones (51 out of 171 , which is $29.82 \%$ ). $H_{7}$ was partially confirmed (in statements II, IV, V).

Regarding the length of doing business, statistically significant differences were found out in neutral responses to statement IV only. $H_{8}$ was not confirmed.

The capital structure is dependent on a number of determinants, and it is shaped, among other things, by business environment, as well as the characteristics of a company's owner/manager. Financial literacy, which is represented by knowledge of advantages and disadvantages of individual sources of financing as well as knowledge of own company's accounting and financial information, significantly influences the shape of a capital structure. A capital structure, which enables companies to grow and develop, certainly affects the competitive position of each individual company [6]. Our results confirmed this opinion, especially for the reason of financial knowledge as the level of education reached caused statistically significant differences between the studied group and this result enhanced the importance of financial knowledge.

The optimal ratio between different financial sources (especially between equity and different types of loans) should enable trouble-free financing of business current needs and strategic plans. Due to the obstacles to external financing in the SME sector and in favorable business environment, financial knowledge can be a crucial factor in the capital structure decisionmaking process.

Although numerous studies have proved the importance of a large number of factors (notably financial ones), the characteristics of company owners and/or managers are still insufficiently explored areas, which can provide an answer to the question asked about the key determinants in the decision-making processes with regard to a capital structure [6]. For this reason, our results can be inspiring for both, entrepreneurs (representatives of practice) as well as educational institutions in the economic field (representatives of theory). For business practice, our results represent a view on knowledge of debt financing in the group studied in 
the Czech Republic. From this point of view, there are positive results concerning a relatively high number of entrepreneurs being well informed about the aspects of financial risk and those considering the necessity of using debt but of less importance in comparison with equity. On the other hand, for the purpose of educational process, our results show a certain gap in debt knowledge (in the sense of its price and risk). With regard on the importance of SMEs for Czech economy and on the other hand on their specific features concerning to the access to external financing, concretely to bank loans we recommend to put more emphasis on entrepreneurial education including above stated financial literacy.

\section{Conclusion}

The aim of this article was to examine knowledge of debt financing (e.g., in the sense of its costs and risk) of SMEs entrepreneurs in the research done in the Czech Republic. At the same time, we tried to reveal the differences in debt knowledge in relation to gender and education of the entrepreneurs and the length of doing business.

The most important findings of our research indicate that vast majority of respondents (83\%) understand the most important aspects of credit risk (responses to statement I were predominantly positive) and $73 \%$ are convinced that it is necessary to use loans, however, under the circumstances of certain values that must not be higher than the value of equity (responses to statement IV were predominantly positive).

We have also found out that only a few respondents have good knowledge of basic characteristics of loans concerning the price and the risk of this financial source. Out of 352 respondents, only $31 \%$ consider a loan to be cheaper than equity (responses to statement II were predominantly negative), and $18 \%$ consider a loan to be less risky than equity (responses to statement III were predominantly negative). These results are not very positive and can indicate knowledge gaps or false knowledge because of previous education or practical experience gained in business. Out of 352 respondents, only $32 \%$ think a loan should be first used for financing current assets of a company (responses to statement $\mathrm{V}$ were predominantly negative). It also suggests false knowledge or gap in knowledge of rules for using debt for financing assets.

Due to the examined factors of gender, education and the length of doing business, only gender and education showed to be the factors statistically differing opinions between male and female entrepreneurs and between university-graduated and otherwise educated entrepreneurs. $82 \%$ out of 87 women recommend using more equity than loans. Respecting the significance level of 0.05 set, this result was statistically significant compared to $69 \%$ out of 265 men. In other words, female entrepreneurs prefer so-called safe sources to the risky ones. $40 \%$ out of 171 university-educated respondents agree with the statement that loans are cheaper than equity, which was statistically more significant than $22 \%$ out of 181 respondents with secondary education and secondary education without graduation examination.

It is it is clear that there are certain limits to our research, especially it is necessary to emphasize regional character of this study. It does not have ambitions to generalize the findings with the aim to predict certain patterns of behavior but to bring new knowledge about opinions on debt financing in SME sector as an important source of Czech economy that can be used especially by various government institutions when searching ways helping this sector, e. g. by organizing different educational courses for SME entrepreneurs or creating educational programs at higher schools or universities. Despite these limits, we believe that our article has brought interesting findings and new incentives for further research that can be aimed also at other factors found out during the questionnaire survey and also influencing debt knowledge and debt experience, such as the age of entrepreneurs or business area. 


\section{Acknowledgement}

The authors would like to thank the Internal Grant Agency of FaME for providing a financial support to carry out this research. Funding was extended through TBU No. IGA/FaME/2017/007 - Finanční a nefinanční faktory úvěrového rizika malých a středních podniků v České republice.

\section{Literature}

[1] BECK, T.; DEMIRGÜC-KUNT, A.: (2006). Small and medium-size enterprises: Access to finance as a growth constraint. Journal of Banking and Finance. 30(11), pp. 2931-2943. DOI: 10.1016/j.jbankfin.2006.05.009

[2] BECK, T.; DEMIRGÜÇ-KUNT, A.: (2008). Access to finance: An unfinished agenda. World Bank Economic Review. 22(3), pp. 383-396. DOI: 10.1093/wber/lhn021

[3] BERGER, A.; ESPINOSA-VEGA, M. A.; FRAME, S.; MILlER, H.: (2005). Debt maturity, risk, and asymmetric information. Journal of Finance. 2005(201), pp. 28952923. DOI: $10.5089 / 9781451862201.001$

[4] BINKS, M.; ENNEW, C.: (1997). The relationship between UK banks and their small business customers. Small Business Economics. 9, pp. 167-178.

[5] CANTON, E.; GRILO, I.; MONTEAGUDO, J.; van der ZWAN, P.: (2013). Perceived Credit Constraints in the European Union. Small Business Economics. 41, pp. 710-715. DOI: $10.1007 / \mathrm{s} 11187-012-9451-\mathrm{y}$

[6] DELIC, A.; PETERKA, S. O.; KURTOVIC, I.: (2016). Is there a relationship between financial literacy, capital structure and Competitiveness of SMEs? Ekonomski Vjesnik. 29(1), pp. 37-50.

[7] DWYER, B.; KOTEY, B.: (2015). Financing SME Growth: The Role of the National Stock Exchange of Australia and Business Advisors. Australian Accounting Review. 25(2), pp. 114-123. DOI: 10.1111/auar.12074

[8] FORLANI, D.: (2013). How Task Structure and Outcome Comparisons Influence Women's and Men's Risk-Taking Self Efficacies: A Multi-Study Exploration. Psychology and Marketing. 30(12), pp. 1088-1107. DOI: 10.1002/mar.20669

[9] FOTR, J.; HNILICA, J.: (2014). Aplikovaná analýza rizika ve finančním managementu a investičním rozhodování. 2. aktualizované a rozšířené vydání Praha: Grada. ISBN 978-80-247-5104-7.

[10] GARWE, D. K.; FATOKI, O.: (2012). The Impact of Gender on SME Characteristics and Access to Debt Finance in South Africa. Development Southern Africa. 29(3), pp. 448-461. DOI: $\underline{10.1080 / 0376835 X .2012 .706040}$

[11] IRWIN, D.; SCOTT, J. M.: (2010). Barriers Faced by SMEs in Raising Bank Finance. International Journal of Entrepreneurial Behavior \& Research. 16(3), pp. 245-259. DOI: $\underline{10.1108 / 13552551011042816 .}$.

[12] JÍLEK, J.: (2000). Finanční rizika. Praha: Grada. ISBN 80-7169-579-3.

[13] JOSEPH, C.: (2013). Advanced credit risk analysis and management. UK: Wiley.

[14] KEPLER, E.; SHANE, S.: (2007). Are Male and Female Entrepreneurs Really That Different? Small Business Research Summary. No 309, 61 pp. 
[15] KLJUČNIKOV, A.; BELÁS, J.: (2016). Approaches of Czech Entrepreneurs to Debt Financing and Management of Credit Risk. Equilibrium. Quarterly Journal of Economics and Economic Policy. 11(2), pp. 343-365. DOI: 10.12775/EQUIL.2016.016

[16] KORTUM, S.; LERNER, J.: (2000). Assessing the contribution of venture capital to innovation. The RAND Journal of Economics. 31(4), pp. 674-692.

[17] KOZUBÍKOVÁ, L.: (2016a). Differences in Innovativeness and Risk-taking between Microenterprises and SMEs: Czech Republic Case Study. Actual Problems of Economics. 177(3), pp. 167-177.

[18] LANGOWITZ, N.; MINNITI, M.: (2007). The Entrepreneurial propensity of women. Entrepreneurship Theory and Practice. 31(3), pp. 341-364. DOI: 10.1111/j.15406520.2007.00177.x

[19] LI, T.; MUNIR, Q.; KARIM, M. R. A.: (2017). Nonlinear relationship between CEO power and capital structure: Evidence from China's listed SMEs. International Review of Economics \& Finance. 47, pp. 1-21. DOI: 10.1016/j.iref.2016.09.005

[20] MARQUES, C. S. E.; FERRIERA, J. J. M.; FERRIERA, F. A. F.; LAGES, M. F. S.: (2013). Entrepreneurial orientation and motivation to start-up a business: evidence from the health service industry. International Entrepreneurship Management Journal. 9(1), pp. 77-94. DOI: $\underline{10.1007 / \mathrm{s} 11365-012-0243-2}$

[21] Mc NAMARA, A.; MURRO, P.; O’DONOHOE, S.: (2017). Countries lending infrastructure and capital structure determination: The case of European SMEs. Journal of Corporate Finance. 43, pp. 122-138. DOI: 10.1016/j.jcorpfin.2016.12.008

[22] MILlÁN, J. M.; CONGREGAdO, E.; ROMÁN, C.; van PRAAG, M.; van STEL, A.: (2014). The value of an educated population for an individual's entrepreneurship success. Journal of Business Venturing. 29(5), pp. 612-632. DOI: 10.1016/j.jbusvent.2013.09.003

[23] MINISTRY OF INDUSTRY AND TRADE OF THE CZECH REPUBLIC: (2015). Report on the development of small and medium enterprises and their support in 2014. Praha: MPO ČR.

[24] MODIGLIANI, F.; MILLER, M. H.: (1958). The cost of capital, corporation finance and the theory of investment. American Economic Review. 48(3), pp. 261-297.

[25] NORTH, D.; BALDOCK, R.; EKANEM, I.: (2010). Is There a Debt Finance Gap Relating to Scottish SMEs? A Demand Side Perspective. Venture Capital. 12(3).

[26] ORTIZ-MOLINA, H.; PENAS, M. F.: (2008). Lending to small businesses: the role of loan maturity in addressing information problems. Small Business Economics. 30(4), pp. 361-383. DOI: $10.1007 / \mathrm{s} 11187-007-9053-2$.

[27] PERVAN, I.; KUVEK, T.: (2013). The relevant Importance of Financial Ratios and Non-Financial variables in Predicting of Insolvency. Croatian Operational research review. 4, pp. 187-197.

[28] RAD, A.; YAZDANFAR, D.; ÖHMAN, P.: (2014). Female and male risk aversion. International Journal of Gender and Entrepreneurship. 6(2), pp. 121-141.

[29] RAHMAN, A.; CIVELEK, M.; KOZUBÍKOVÁ, L.: (2016). Proactiveness, Competitive Aggressiveness and Autonomy: A Comparative Study from the Czech Republic. Equilibrium. Quarterly Journal of Economics and Economic Policy. 11(3), pp. 631-650. DOI: 10.12775/EQUIL.2016.028 
[30] RAUCH, A.; RIJSDIJK, S. A.: (2013). The effects of general and specific human capital on long-term growth and failure of newly founded businesses. Entrepreneurship Theory and Practice. 37(4), pp. 923-941. DOI: 10.1111/j.1540-6520.2011.00487.x

[31] REŽŇÁKOVÁ, M.: (2006). Možnosti minimalizace platebního rizika. MM Průmyslové spektrum. pp. 116-117. ISSN 1212-2572.

[32] ROSTAMKALAEI, A.; FREEL, M.: (2017). Business advice and lending in small firms. Environment and Planning C: Politics and Space. 35(3), pp. 537-555. DOI: $\underline{10.1177 / 0263774 X 16665620}$

[33] ZHAO, S.; ZENG, M.: (2014). Theory of SMEs financial risk prevention and control. In: Proceedings of the 2014 International Conference on Education, Management and Computing Technology. pp. 514-517. ISBN 978-94-6252-016-5. DOI: 10.2991/icemct$\underline{14.2014 .126}$

[34] SYNEK, M.; KISLINGEROVÁ, E.: (2015). Podniková ekonomika. 6. přepracované a doplněné vydání, Praha: C.H. Beck, Beckovy ekonomické učebnice. ISBN 978-807400-274-8.

[35] TREICHEL, M. Z.; SCOTT, J. A.: (2006). Women-owned businesses and access to bank credit: Evidence from three surveys since 1987. Venture Capital. 8(1), pp. 51-67. DOI: $\underline{10.1080 / 13691060500453726}$

[36] WANG, W.: (2012). How the small and medium-sized enterprises' owners' credit features affect the enterprises' credit default behaviour? E3 Journal of Business Management and Economics. 3(2), pp. 090-095.

[37] YAZDANFAR, D.; ÖHMAN, P.: (2016). Capital structure dynamics among SMEs: Swedish empirical evidence. The Journal of Risk Finance. 17(2), pp. 245-260. DOI: $\underline{10.1108 / J R F-04-2015-0040}$

Ing. Ludmila Kozubíková, Ph.D.; Bc. Robin Klička; Bc. Darek Maňák 


\section{ZNALOSTI PODNIKATELŮ MALÝCH A STŘEDNÍCH PODNIKU゚ ČESKÉ REPUBLIKY Z OBLASTI CHARAKTERISTIK DLUHOVÉHO FINANCOVÁNÍ}

Vzhledem k nedostatku interních a vlastních zdrojů v malých a středních podnicích (MSP), je dluhové financování nevyhnutelnou součástí celkové hodnoty kapitálu podniku. Cílem tohoto článku je zjistit, jaké znalosti dluhového financování (ve smyslu jeho ceny a rizika) mají podnikatelé MSP. Současně jsme se pokusili zjistit rozdíly v těchto znalostech ve vztahu k věku a vzdělání podnikatelů a délce podnikání. Data byla získána prostřednictvím dotazníkového šetření od 352 podnikatelů MSP v České republice. Naše výsledky ukázaly, že $83 \%$ podnikatelů rozumí nejdůležitějším aspektům úvěrového rizika a 73 \% z nich si myslí, že podnikatel potřebuje používat určité množství úvěrů. $\mathrm{V}$ tomto tvrzení byly zjištěny statisticky významné rozdíly mezi podnikateli muži a ženami.

\section{KENNTNISSE DER CHARAKTERISTIKEN DER SCHULDENFINANZIERUNG AUF DEM SEKTOR KLEINER UND MITTLERER BETRIEBE IN DER TSCHECHISCHEN REPUBLIK}

Im Hinblick auf den Mangel an internen und eigenen Quellen in kleinen und mittleren Betrieben ist die Schuldenfinanzierung ein unerlässlicher Bestandteil des Betriebskapitals. Das Ziel dieses Beitrags besteht in der Feststellung, was für Kenntnisse der Schuldfinanzierung (im Sinne von deren Preis und Risiko) die Unternehmer in kleinen und mittleren Betrieben mitbringen. Gleichzeitig versuchen wir, die Unterschiede innerhalb solcher Kenntnisse in Bezug auf das Alter und die Ausbildung der Unternehmer sowie auf die bisherige Unternehmensdauer festzustellen. Die Daten wurden mittels einer an 352 Unternehmern mittlerer und kleinerer Betriebe Fragebogenumfrage erhoben. Die Ergebnisse zeigen, dass $83 \%$ der Unternehmer eine Vorstellung von den wichtigsten Aspekten des Kreditrisikos besitzen und $73 \%$ von ihnen meinen, dass der Unternehmer auf eine gewisse Anzahl von Krediten angewiesen ist. In dieser Behauptung wurden statistisch relevante Unterschiede zwischen männlichen und weiblichen Unternehmern verzeichnet.

\section{WIEDZA NT. CECH FINANSOWANIA DŁUŻNEGO W SEKTORZE MAŁYCH I ŚREDNICH PRZEDSIĘBIORSTW W REPUBLICE CZESKIEJ}

Ze względu na niedobór wewnętrznych i własnych środków w małych i średnich przedsiębiorstwach (MŚP) finansowanie dłużne stanowi nieunikniony element ogólnej wartości kapitału przedsiębiorstwa. Celem niniejszego artykułu jest sprawdzenie wiedzy nt. finansowania dłużnego ( $\mathrm{w}$ aspekcie jego ceny i ryzyka), jaką posiadając przedsiębiorcy prowadzący MŚP. Jednocześnie podjęto próbę ustalenia, jakie są różnice w posiadanej wiedzy w zależności od wieku i wykształcenia przedsiębiorców i czasu prowadzenia działalności gospodarczej. Dane pozyskano w badaniu ankietowym od 352 przedsiębiorców prowadzących MŚP w Republice Czeskiej. Wyniki badań wskazują, że 83 \% przedsiębiorców rozumie najważniejsze aspekty ryzyka kredytowego a 73 \% z nich uważa, że przedsiębiorca potrzebuje korzystać $\mathrm{z}$ pewnej liczby kredytów. W tym stwierdzeniu stwierdzono statystycznie istotne różnice między prowadzącymi działalność gospodarczą kobietami a mężczyznami. 